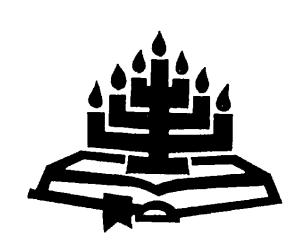

\title{
Die konsep van gelykheid in die lig van die Suid-Afrikaanse Grondwet (1996) en die Skrif
}

\author{
N. (Nico) Vorster \\ Skool vir Kerkwetenskappe \\ Potchefstroomse Universiteit vir $\mathrm{CHO}$ \\ POTCHEFSTROOM \\ E-pos: nvorster@telkomsa.net
}

\begin{abstract}
Equality in the light of the 1996 South African Constitution and Scripture In the debate on the role of women in the church the principle of equality (especially gender equality) is of particular importance. Churches and theologians are confronted by a twofold question, that is:
\end{abstract}

- Does Scripture support gender inequality as a consequence of the patriarchal context in which it originated?

- Are churches that prevent women from serving in the offices not guilty of gender discrimination?

Before these questions can be answered theologians should clarify the concept of equality. The aim of this article is to compare the biblical concept of equality with the ethical content with which the Constitutional Court imbues the South African constitutional value of equality. The central theoretical argument of this article is that there is a fundamental difference in content between the biblical concept of equality and the South African constitutional value of equality. The main differences in content between the two concepts of equality will be highligted by way of comparison. After the comparison of these concepts, a few observations will be made which are relevant for the debate on the role of women in the church.

\section{Opsomming}

Die konsep van gelykheid in die lig van die Suid-Afrikaanse Grondwet (1996) en die Skrif

In die debat oor die rol van die vrou is dit belangrik om na te dink oor die beginsel van gelykheid, spesifiek geslagsgelykheid. Kerke en teoloë word tans deur'n tweeledige vraag gekonfronteer: 
- Bevorder die Skrif nie dalk, vanweë die patriargale konteks waarbinne dit ontstaan het, 'n vorm van geslagsongelykheid nie?

- Maak kerke wat vroue weerhou van diens in die ampte hulleself nie skuldig aan geslagsdiskriminasie nie?

Alvorens hierdie vrae beantwoord kan word is dit nodig vir teoloë om na te dink oor die konsep van gelykheid. Die doel van hierdie artikel is om die Bybelse konsep van gelykheid te vergelyk met die etiese inhoud wat die Suid-Afrikaanse Grondwetlike Hof tans aan die konsep van gelykheid gee. Die sentrale teoretiese argument van hierdie artikel is dat daar 'n fundamentele verskil bestaan tussen die inhoud van die Bybelse konsep van gelykheid en die etiese inhoud wat die Grondwetlike Hof aan gelykheid gee. Die verskille in inhoud sal by wyse van vergelyking benadruk word. Na die vergelyking van hierdie konsepte sal enkele opmerkings gemaak word wat vir die debat oor die rol van die vrou in die kerk van belang is.

\section{Inleidend}

In die debat oor die plek van die vrou in die kerk kom die beginsel van gelykheid, en spesifiek geslagsgelykheid, prominent ter sprake. Die tweërlei vraag waarmee kerke en teoloë gekonfronteer word, raak sowel die integriteit van die Skrif as dié van die kerk, naamlik:

- Bevorder die Skrif nie vanweë die patriargale konteks waarbinne dit ontstaan het, 'n prinsipiële ongelykheid tussen man en vrou nie?

- Kom kerke se weerhouding van vroue om in die amp te dien nie neer op geslagsdiskriminasie nie?

Alvorens hierdie vrae beantwoord kan word, is dit nodig dat teoloë helderheid kry oor die vraag waarop die konsep van gelykheid presies dui.

In hierdie artikel sal gepoog word om 'n vergelyking te tref tussen die Bybelse konsep van gelykheid en die etiese inhoud wat die SuidAfrikaanse Grondwetlike Hof aan die grondwetlike waarde van gelykheid gee. Die sentrale teoretiese argument van hierdie artikel is dat daar 'n fundamentele prinsipiële verskil is tussen die Bybelse konsep van gelykheid en die Suid-Afrikaanse grondwetlike konsep van gelykheid wat aansluiting vind by die globale menseregtediskoers. Die prinsipiële onderskeid tussen hierdie twee konsepte van gelykheid sal benadruk word deur die twee konsepte met mekaar te vergelyk. Daarna sal in die lig van die vergelyking enkele opmerkings gemaak word wat vir die debat oor die plek van die vrou in die kerk van belang is. 
Allereers word gefokus op die inhoud wat die Suid-Afrikaanse Grondwetlike Hof aan die grondwetlike waarde van gelykheid gee.

\section{Gelykheid in die Suid-Afrikaanse Grondwet}

Die Suid-Afrikaanse Grondwet (1996) lê in die lig van Suid-Afrika se ongelyke en diskriminerende verlede besonder baie klem op gelykheid. In President of the Republic of South Africa and another v Hugo 1997(6) BC LR 708 (CC) [par 74]) beskryf regter Kriegler die Suid-Afrikaanse Grondwet as 'n egalitêre grondwet:

The South African Constitution is primarily and emphatically an egalitarian constitution. The supreme laws of comparable constitutional states may underscore other principles and rights. But in the light of our own particular history, and our vision for the future, a constitution was written with equality at its centre. Equality is our Constitution's focus and organising principle.

Hoewel die konsepte van gelykheid en nie-diskriminasie in internasionale konvensies en buitelandse regspraak aansien geniet, en artikel 39 van die Grondwet howe verplig om by die uitleg van die Handves van Regte buitelandse regspraak in ag te neem, lê die Suid-Afrikaanse howe baie klem op 'n eiesoortige Suid-Afrikaanse verstaan van gelykheid, juis omdat Suid-Afrika se verlede besonder relevant vir die konsep van gelykheid is (Prinsloo $v$ Van der Linde and another 1997 (6) BCLR 759 (CC) [par 21]).

Suid-Afrika se geskiedenis word deur regter O' Regan in Brink $v$ Kitshoff no 1996 (6) BCLR 1489 (CC) [par 41, 42, 43, 44] beskryf as 'n verlede waarin sistematiese vorme van diskriminasie in die sosiale samestelling opgeneem is. Hierdie diskriminasie was nie net rasgebaseerd nie. Ander vorme van ongelykheid, soos geslagsongelykheid, het ook deel geword van die Suid-Afrikaanse sosiale samestelling. Die nuwe Grondwet is teen dié agtergrond saamgestel. Die doel van die Grondwet, volgens die aanhef, is om alle vorme van geïnstitusionaliseerde diskriminasie en ongelykheid uit die Suid-Afrikaanse sosiale samestelling te verwyder (Brink v Kitshoff, no 1996 (6) BCLR 1489 (CC) [par 44]).

Op verskeie plekke in die Grondwetlike teks word die Grondwet se verbintenis tot die beginsel van gelykheid uitgestippel. Artikel 1(a en b) beskryf die Republiek van Suid-Afrika as 'n soewereine en demokratiese staat, wat gegrond is op "die bereiking van gelykheid", en "nie-rassigheid en nie-seksisme". Artikel 7(1) stel dat die Handves van Regte die demokratiese waardes van menswaardigheid, gelykheid en vryheid bevestig. Artikel 36 bepaal dat die regte in die Handves van Regte slegs ingeperk kan word tot die mate waarin die beperking redelik en 
regverdigbaar is in 'n oop en demokratiese samelewing gebaseer op menswaardigheid, gelykheid en vryheid. Artikel 39 vereis verder dat 'n hof, tribunaal of forum by die uitleg van die Handves van Regte waardes moet bevorder wat 'n oop en demokratiese samelewing, gebaseer op menswaardigheid, gelykheid en vryheid, ten grondslag lê.

Uit bogenoemde verwysings word dit duidelik dat die Grondwet gelykheid as 'n grondwaarde handhaaf. Die vraag is: Watter soort gelykheid probeer die howe bevorder?

\subsection{Formele en substantiewe gelykheid}

Gewoonlik word in die reg onderskei tussen formele gelykheid en substantiewe gelykheid (Van Reenen, 1997:153). Formele gelykheid gaan van die standpunt uit dat alle mense gelyke draers van regte binne 'n regstelsel is. Gelykheid word verkry deur aan alle mense dieselfde regte toe te ken, ooreenkomstig die norm van nie-voorkeurbehandeling. Die agtergrond en omstandighede van individue word nie spesiaal in ag geneem nie. ' $n$ Formele vorm van gelykheid stel nie belang in strukturele verskille in gelykheid nie, en sal dus nie met die gedagte van regstellende aksie werk nie.

Substantiewe gelykheid neem, aan die ander kant, die sosiale en ekonomiese omstandighede in ag wat ongelykheid tussen mense en groepe kan veroorsaak. Hierdie siening van gelykheid is meer geneig om met die idee van regstellende aksie te werk, wat impliseer dat positiewe stappe geneem word om geïnstitusionaliseerde ongelykhede uit die samelewing te verwyder (vgl. Van Reenen, 1997:153). Die Grondwet handhaaf duidelik 'n substantiewe siening van gelykheid, omdat dit voorsiening maak vir maatreëls wat heersende sosiale en ekonomiese ongelykhede uit die weg kan ruim (vgl. Van Reenen, 1997:164). Artikel 9(2) van die Grondwet bepaal byvoorbeeld die volgende:

Ten einde die bereiking van gelykheid te bevorder, kan wetgewende en ander maatreëls getref word wat ontwerp is vir die beskerming of ontwikkeling van persone, of kategorieë van persone, wat deur onbillike diskriminasie benadeel is.

Die Konstitusionele Hof het in verskeie uitsprake dit duidelik gestel dat die Hof, in ooreenstemming met die gelykheidsklousule van die Grondwet, probeer om 'n substantiewe konsep van gelykheid te ontwikkel. In National Coalition for Gay and Lesbian Equality v Minister of Justice and others 1998 (12) BCLR 1517 (CC) [par 62] stel regter Ackermann dat die Grondwet sowel substantiewe as remediërende gelykheid bevorder: 
[W]e have encapsulated the notion of substantive as opposed to formal equality. Section 9 of the 1996 Constitution, like its predecessor, clearly contemplates both substantive and remedial equality. Substantive equality is envisaged when section 9(2) unequivocally asserts that equality includes 'the full and equal enjoyment of all rights and freedoms'.

Die vroulike geslag word in artikel 9(3) geïdentifiseer as 'n voorheen benadeelde groep wie se historiese ongelykheid deur remediërende stappe reggestel moet word.

Uit bogenoemde word dit duidelik dat die howe 'n omvattende konsep van gelykheid het. Gelykheid impliseer nie net gelyke regte en gelyke toegang tot die reg nie, maar dit vereis ook die regstelling van historiese ongelykhede in die samelewing deur positiewe remediërende stappe. Die howe werk dus met 'n uitkomsgebaseerde konsep van gelykheid.

\subsection{Regverdige en onregverdige diskriminasie}

Gelykheid beteken nie noodwendig eenvormigheid of eendersheid nie. Differensiasie is binne 'n moderne staat onvermydelik omdat die wette van ' $n$ land nie alle burgers op 'n identiese wyse kan behandel nie. Die Suid-Afrikaanse konteks van ongelykheid en die nuwe Grondwet se verbintenis tot regstellende stappe maak differensiasie nog meer onvermydelik. Aangesien eenvormige behandeling voor die reg onmoontlik is, en sekere situasies differensiasie vereis, kan alle vorme van differensiasie nie getipeer word as onregverdige diskriminasie nie. Die Grondwet onderskei daarom in die gelykheidsklousule tussen differensiasie wat op billikke en onbillikke diskriminasie neerkom. Die vraag wat ontstaan is egter: Wanneer is diskriminasie regverdig en wanneer is dit onregverdig?

Artikel 9(3) van die Grondwet noem verskeie gronde waaraan diskriminasie as onregverdig uitgeken kan word, naamlik: ras, geslagtelikheid, geslag, swangerskap, huwelikstaat, etniese of sosiale herkoms, kleur, seksuele oriëntasie, ouderdom, gestremdheid, godsdiens, gewete, oortuiging, kultuur, taal en geboorte. Die gespesifiseerde gronde in artikel 9(3) is geïdentifiseer teen die agtergrond van Suid-Afrika se verlede van diskriminasie. Wanneer die genoemde gronde aangetas word, ontstaan die moontlikheid dat 'n persoon van sy inherente waardigheid ontneem kan word (Harksen v Lane, and others 1997 (11) BCLR 1517 (CC) [par 49]). Die lys van gronde wat genoem word, is egter nie allesomvattend nie. Die howe moes daarom ook maatstawwe vind om te oordeel of ongelyke behandeling ten opsigte van nie-omskrewe gronde regverdig is al dan nie (Venter, 2000:9). 
In Harksen v Lane and others 1997 (11) BCLR 1517 (CC) is vroeëre hofuitsprake oor die maatstawwe waaraan regverdige en onregverdige diskriminasie gemeet moet word, gesistematiseer in 'n logiese volgorde. Verskeie stappe van beoordeling is onderskei. In die eerste stap word gevra of 'n bepaling differensieer tussen mense of kategorieë van mense? Indien sodanige differensiasie plaasvind, moet ondersoek ingestel word na die rasionele verband tussen die differensiasie wat ter sprake is en die legitieme regeringsdoel wat dit probeer bereik. As daar geen rasionele verband is nie, word die reg op gelykheid geskend. Maar selfs al is daar 'n verband, kan die differensiasie nog steeds op diskriminasie neerkom (Harksen $v$ Lane, and others 1997 (11) BCLR 1517 (CC) [par 42]). In die tweede stap word gevra of die differensiasie op onregverdige diskriminasie neerkom? Twee stadiums van analise word gevolg ten einde 'n antwoord op die vraag te kry. In die eerste stadium moet vasgestel word of die differensiasie op diskriminasie neerkom. As die differensiasie enige van die gronde genoem in artikel 9(3) raak, kom dit op diskriminasie neer. As die differensiasie nie ten opsigte van enige genoemde grond plaasvind nie, sal die diskriminerende aard van die differensiasie, al dan nie, afhang van die vraag of dit gebaseer is op eienskappe wat die potensiaal het om fundamentele menswaardigheid aan te tas (Harksen $v$ Lane, and others 1997 (11) BCLR 1517 (CC) [par 45-47]). In die tweede stadium van analise word gevra of die diskriminasie op onregverdige diskriminasie neerkom. As die diskriminasie ten opsigte van enige genoemde gronde plaasgevind het, neem die Hof aan dat die diskriminasie onregverdig was. As die diskriminasie ten opsigte van 'n ongespesifiseerde grond plaasgevind het, moet die aanklaer onregverdige optrede kan aantoon. Die toets van onregverdigheid sal primêr fokus op die impak van die diskriminasie op die aanklaer en ander wat hulleself in 'n soortgelyke situasie bevind. Die posisie van die aanklaer in die samelewing asook die invloed van vorige diskriminasiepatrone op die aanklaer sal in ag geneem word (Harksen $v$ Lane, and others 1997 (11) BCLR 1517 (CC) [par 48-52]).

In die derde stap moet die Hof besluit of die bepaling wat op onregverdige diskriminasie neerkom, geregverdig kan word onder die beperkingsklousule (Harksen v Lane, and others 1997 (11) BCLR 1517 (CC) [par 53]). Indien nie, vind onregverdige diskriminasie plaas.

Uit die Grondwet se onderskeid tussen billike en onbillike diskriminasie word dit duidelik dat gelykheid ten nouste verbind word aan ' $n$ regstellende vorm van geregtigheid wat geregtigheid soms deur 'n proses van omgekeerde diskriminasie probeer bevorder. 


\subsection{Gelykheid en menswaardigheid}

Die Suid-Afrikaanse howe beskou menswaardigheid as die kernwaarde in die Suid-Afrikaanse Grondwet. Dit blyk uit verskeie uitsprake van die Grondwetlike Hof (vgl. State v Makwanyane and other 1995 (6) BCLR 665 (CC), [par 148]), en ook die rangorde wat die Grondwet telkens aan die drie grondwaardes van die Grondwet gee. Menswaardigheid het as kernwaarde 'n fondamentleggende en samebindende funksie in regspraak.

In aansluiting by die dominante Westerse paradigma van menseregte word menswaardigheid deur die howe gesien as die inherente en onontneembare besit van elke individu. Menswaardigheid word gefundeer in menswees as sodanig en nie in 'n ontologiese natuurwet of in metafisiese idees nie. Dit vorm, volgens die howe, die bron en basis van alle ander regte met die gevolg dat geen persoon van sy waardigheid ontneem kan word nie (vgl. State v Makwanyane and other 1995 (6) BCLR 665 (CC), [par 148]). Menswaardigheid is daarom 'n onvervreembare reg. Alle individue het gelyke waardigheid. Daarom kan elke burger op gelyke behandeling en gelyke vryhede voor die howe aanspraak maak.

Dit is reeds gestel dat menswaardigheid deur die howe as die vernaamste maatstaf gebruik word om te bepaal of diskriminasie regverdig is of nie. In Prinsloo v Van der Linde and another 1997 (6) BCLR 665 (CC) [par 31] word onregverdige diskriminasie beskryf as "treating persons differently in a way which impairs their fundamental dignity as human beings, who are inherently equal in dignity". Die belangrikheid van menswaardigheid vir gelykheid is verder deur die Hof bevestig deur 'n aanhaling uit Egan $v$ Canada:

... inherent human dignity is at the heart of individual rights in a free and democratic society ... Equality, as that concept is enshrined as a fundamental human right within s. 15 of the Charter, means nothing if it does not represent a commitment to recognising each person's equal worth as a human being, regardless of individual differences (Prinsloo v Van der Linde and another 1997 (6) BCLR 665 (CC), [par 32]).

Die verband tussen menswaardigheid en gelykheid is verder uitgespel in uitsprake waarin geslagsgelykheid, huwelikstatus en seksuele oriëntasie ter sprake gekom het. In National Coalition for Gay and Lesbian equality and others $v$ Minister of Justice and others 1998 (12) BCLR 1517 (CC) waarin die kriminalisering van sodomie ongrondwetlik verklaar is, word dit duidelik gestel dat die doel van gelykheidsregpleging is om te keer dat individue of groepe tot minderwaardigheid verlaag kan word, en om te 
verseker dat alle burgers hulleself kan verwesenlik sonder om gemarginaliseer te word. In President of the Republic of South Africa and another v Hugo 1997 (6) BCLR 708 (CC) [par 80] is menswaardigheid in verband gebring met die vrou se reg om keuses oor haar eie identiteit te maak. Om die vrou te beskryf as die primêre sorgdraer van haar kinders, sal volgens die Hof die vrou se reg om haar eie identiteit te kies, asook haar gelyke waardigheid, in gedrang bring. In Harksen $v$ Lane and others 1997 (11) BCLR 1517 (CC) [par 124] word 'n siening van die huwelik waarin man en vrou as ongelyke vennote gesien word, beskryf as 'n aantasting van menswaardigheid:

Being trapped in a stereotyped and outdated view of marriage inhibits the capacity for self-realisation of the spouses, affects the quality of their relationship with each other as free and equal persons within the union, and encourages society to look at them not as 'a couple' made up of two persons with independent personalities and shared lives, but as 'a couple' in which each loses his or her individual existence. If this is not a direct invasion of fundamental dignity it is clearly of comparable impact and seriousness.

Die howe sluit hiermee aan by die universele menseregtediskoers se siening dat 'n prinsipiële onderskeiding tussen manlike en vroulike rolle op diskriminasie en stereotipering neerkom (vgl. Convention on the elimination of all forms of discrimination against women, 1979:par 1, 5(a) - kyk United Nations, 1979).

Uit bogenoemde aanhalings blyk dit dat die howe die waardes van menswaardigheid en gelykheid nou aan mekaar verbind. Die waarde van gelykheid berus op die idee dat alle mense inherent gelyke waardigheid besit. Onregverdige diskriminasie vind plaas wanneer die gelyke waardigheid van 'n persoon ontken word. Gelykheid vloei dus voort uit menswaardigheid wat die besit van elke mens is, en wat die fondament vir alle ander individuele regte vorm. Gelykheid word aangetas wanneer menswaardigheid aangetas word en omgekeerd.

\subsection{Samevattende opmerkings oor die Grondwetlike siening van gelykheid}

- Suid-Afrika se verlede van ongelykheid weeg swaar in gelykheidsregspraak. Persone wat voorheen benadeel was, se regte word met groot omsigtigheid beskerm. Dit blyk uit die omskrewe gronde waaraan onregverdige diskriminasie gemeet word, en wat in artikel 9(3) voorkom. Die howe toon daarom 'n besondere sensitiwiteit vir vroueregte, omdat die vroulike geslag as 'n voorheen benadeelde groep gesien word. 
- Die howe probeer om 'n substantiewe of uitkomsgebaseerde vorm van gelykheid te vestig deur onder meer 'n proses van omgekeerde diskriminasie. Daarom word 'n term soos regverdige diskriminasie gebruik. Suid-Afrikaanse regspraak sal in die toekoms deur grootskaalse differensiasie voor die reg gekenmerk word, omdat die howe met ' $n$ regstellende of distributiewe vorm van geregtigheid werk. Remediërende stappe word geneem om geslagsongelykheid uit die samelewing te weer.

- Die waarde van gelykheid word deur die howe grootliks gefundeer in menswaardigheid wat as die inherente besit van elke mens beskou word. Gelykheid word daarom ook gesien as 'n inherente aangebore reg van die mens. In Harksen $v$ Lane and others 1997 (11) BCLR 1517 (CC) word gestel dat die gelykwaardigheid van die vrou in gedrang kom wanneer sy as 'n ongelyke draer van regte beskou word, sy deur rolverwagtings daarvan weerhou word om haar eie identiteit uit te leef, en sy daarvan weerhou word om haarself te verwesenlik. Dit is in ooreenstemming met die moderne Westerse tradisie se eenvormige siening van geslagsgelykheid wat nie tussen manlike en vroulike rolle differensieer nie, omdat dit op stereotipering sou neerkom (vgl. Convention on the elimination of all forms of discrimination against women, 1979:par 1, 5(a) - kyk United Nations, 1979).

Uit bogenoemde gegewens blyk dit duidelik dat praktyke in die kerk soos die weerhouding van die vrou uit die amp teen die hele gees en strekking van die Grondwet ingaan. 'n Belange-afweging sal wel plaasvind. Howe sal artikel 36 en ander regte, soos die reg op godsdiensvryheid, in ag neem. Hoewel dit moeilik is om te bepaal of die howe praktyke soos die weerhouding van die vrou uit die amp as ongrondwetlik sal verklaar wanneer dit aan die Grondwet getoets word, bring dit wel die kerk in spanning met die menseregte-etos van die moderne Suid-Afrikaanse samelewing.

\section{Gelykheid in die Skrif}

\subsection{Hermeneutiese uitgangspunt}

Die Skriftuurlike konsep van gelykheid word in hierdie artikel op 'n holistiese wyse benader deur te fokus op sentrale Bybelse temas wat in sowel die $\mathrm{Ou}$ en Nuwe Testament gevind word. 'n Tematies-heilshistoriese benadering word gevolg. Dit hou die volgende in:

- Die eenheid van die Skrif as die Woord van God word gehandhaaf. Die finale teks wat deur die gemeenskap as kanoniek aanvaar is, 
word as die geïnspireerde en gesagvolle teks aanvaar. Die mening wat in hierdie artikel uitgespreek word, is dat die soeke van die kritiese teologie om 'n meta-narratief te ontwikkel wat die ware teks agter die teks sou wees, naïef is, en berus dit op 'n positiwistiese wetenskaplike uitgangspunt.

- Die algehele openbaring van God word as uitgangspunt geneem. So word gepoog om nie in 'n fragmentariese gebruik van die Skrif te verval nie. Terselftertyd gee dit 'n geloofwaardige fundering aan gelykheid, omdat dominante temas in die Skrif, en nie geïsoleerde tekste nie, as uitgangspunt gebruik word. Die teoloog word in staat gestel om tekste wat oënskynlik ongelykheid legitimeer, op 'n geldige en betroubare wyse te verklaar binne die breëre verband van die Skrif.

- So 'n verklaring neem die Skrif self as hermeneutiese uitgangspunt. Hoewel die teoloog die Skrif altyd met 'n mate van voorverstaan lees, is die gevaar van ideologisering en misbruik minder as in die geval van die kontekstuele hermeneutiek se benadering waar die mens self die agent van betekenis gemaak word deurdat moderne sosiale analises tot norms verhef word in die lig waarvan die Skrif geherinterpreteer word. Deurdat die Skrif self as hermeneutiese uitgangspunt geneem word, word gepoog om die gesagvolheid van die Skrif te bewaar, sonder dat interpretasie op 'n fundamentalistiese wyse gelykgestel word aan openbaring.

Vervolgens word op enkele belangrike Bybelse temas gefokus wat vir die konsep van gelykheid van belang is.

\subsection{Gelykheid in die Ou Testament}

\subsubsection{Die mens as beeld van God}

Daar was in die loop van die geskiedenis uiteenlopende verklarings binne die teologie vir die betekenis van die imago Dei. Die imago Dei is dikwels vereenselwig met ontiese kwaliteite in die mens self. Binne die Aristoteliaanse tradisie en die Verligting is die imago Dei met die menslike rede en die inherente goedheid van die mens geïdentifiseer (Ramsey, 1993:250). Augustinus en Schleiermacher het die beeld van God in geestelike eienskappe van die mens gaan soek. Augustinus het die imago Dei geïdentifiseer met die krag van die siel, geheue, intellek en wil, terwyl Schleiermacher die beeldskap gesoek het in die mens se persoonlike en moreel-religieuse lewe (vgl. Fouché, 1988:32). Binne die Katolieke en Oosters-Ortodokse tradisie is in navolging van Irenaeus, op grond van Genesis 1:26, 'n onderskeid gemaak tussen die beeld van God in 'n natuurlike sin (imago), en die beeld van God in 'n bonatuurlike sin (similitudo). Die imago dui dan op die mens se natuurlike beeld van 
God wat bestaan uit vernuf en vryheid, terwyl die similitudo dui op 'n bonatuurlike gelykenis van God (Wentsel, 1987:599). Binne die twintigste-eeuse teologie word die imago Dei ook soms vereenselwig met inherente eienskappe in die mens. Teoloë soos Emil Brunner en Wolfhart Pannenberg soek die imago Dei byvoorbeeld in die persoonlike struktuur van die mens.

Die siening dat die mens se beeldskap van God op sekere ontiese hoedanighede in die mens dui, skep egter probleme:

- Daar bestaan geen Skriftuurlike getuienis vir die verstaan van die imago Dei as inherente hoedanighede van die mens nie. BuiteBybelse filosofiese kategorieë word gewoonlik gebruik om die menslike beeldskap op 'n ontiese wyse te verklaar.

- Die ontiese standpunt gaan met 'n atomistiese mensbeeld om. Die imago Dei word gelokaliseer in sekere eienskappe van die mens, terwyl ander hoedanighede gereduseer word tot 'n laer orde. Die Skrif ken geen atomistiese of dualistiese mensbeeld waarin sekere hoedanighede verhef word bo ander nie.

- Die ontiese standpunt maak die mens los van sy gerigtheid tot God en afhanklikheid van God. Indien die mens se beeldskap in sy ontiese hoedanighede aanwesig was, sou die mens op homself aangewese kon wees. Die Verligting het die beeldskap sodoende losgemaak van die verhouding tussen God en mens en die mens verselfstandig teenoor die Een na wie se beeld hy geskape is.

As die imago Dei nie opgaan in die inherente eienskappe van die mens nie, waarop dui dit dan?

In Genesis 1:26 word twee uitdrukkings vir die beeldskap van die mens

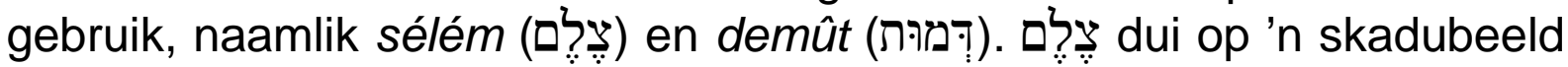
of afbeelding, terwyl דָרָּ op 'n refleksie of kopie kan dui (vgl. Keil \& Delitzch, s.a.: 63; Wentsel, 1987:593 en Durandt 1982:163). Geen duidelike definieerbare onderskeid bestaan tussen dié twee uitdrukkings

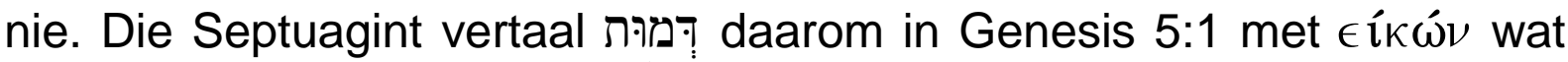

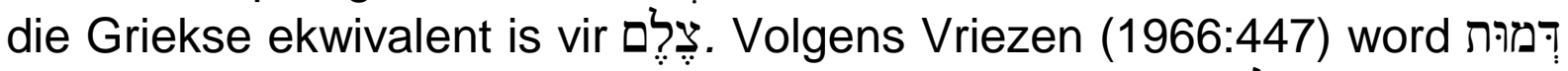
in Genesis 1:26 gebruik om 'n nadere omskrywing by צֶֶ te gee. Dit voeg nie 'n nuwe element by die beeldskap by nie. Die dogma van 'n dubbele beeldskap, ingevolge waarvan die een deel van die beeldskap met die sondeval verlore gegaan het en die ander nie, het eksegeties gesproke, geen gronde nie. Die gebruik van die twee uitdrukkings in Genesis 1:26 dien waarskynlik eerder 'n polemiese doel. Teenoor die oud-Oosterse tradisie wat geglo het dat die mens uit Goddelike bloed geskape is, beklemtoon Genesis dat die mens nie 'n liggaamlike beeld 
van God is nie, maar wel 'n gelykenis-beeld. דִָּּוּת wys daarop dat daar 'n wesentlike verskil tussen God en mens is. Anders as die oud-Oosterse wêreld ken die Skrif geen wesenseenheid tussen God en mens nie (vgl. Vriezen, 1966:187-189).

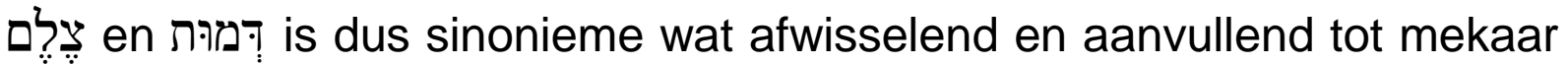
gebruik word (Keil \& Delitzch, s.j: 63). Dit stel die mens in 'n verhouding tot God en beskryf die gemeenskap tussen God en mens. Geen wesenseenheid met God of ontiese eienskappe van die mens self word deur hierdie woorde uitgedruk nie. Die beeldskap gaan nie op in die inherente hoedanighede van die mens nie, maar dit omvat wel die ganse mens na sy geestelike en liggaamlike bestaan in sy verhouding tot God.

Die verhoudingsgerigtheid van die imago Dei blyk uit die feit dat die beeldskap in die Skrif dien as 'n fundering vir God se gemeenskap met die mens, soos dit in die verbond ter sprake kom (vgl. Vriezen, 1966: 187). As soewereine Skepper en Verbondsgod tree God in 'n vaderkindverhouding met die mensheid, en ken Hy 'n bepaalde status aan die mens toe. Hy maak die mens die kroon van sy skepping. Die mens staan, anders as die dierewêreld, in 'n unieke verhouding tot God. Daar is 'n bepaalde onaantasbaarheid aan die mens, sodat daar nie oor die lewe, bewegings en privaatheid van die mens beskik kan word soos in die geval van diere nie (vgl. Gen. 9:6; König, 1993:94). Op hierdie wyse word ' $n$ besonderse waardigheid aan die hele mensheid toegeken.

As kroon van God se skepping moet die mens God se deugde reflekteer (Van Wyk, 2000). Calvyn lê baie klem op die feit dat die mens as 'n spieëlbeeld van God se beeld beskou kan word (Inst. 1.15.4). In die Nuwe Testament word die beeldskap duidelik in verband gebring met 'n reflektering of uitstraling van die heerlikheid van God. Soos wat Christus die heerlikheid van God uitstraal, moet die mens die heerlikheid van Christus uitstraal (vgl. 2 Kor. 3:18). Hierdie weerspieëling van deugde vind plaas binne die konteks van 'n verhouding tussen God en mens.

Hoewel die beeldskap van die mens nie met sy heerskappy oor die skepping vereenselwig kan word nie, word sy beeldskap wel op 'n besondere wyse weerspieël in sy verteenwoordiging van God op aarde. God gee aan die mens beheer oor sy skepping, en vra van die mens om dit te bewaak en beheers (vgl. Wentsel, 1987:588).

Die mens vertoon nie net die beeld van God in sy heerskappy oor die natuur nie, maar ook in menslike kultuurvorming. God skep die mens as tweeheid, as man en vrou (Gen. 1:27, 2:18 en 5:1). By Barth (vgl. 1960: 243) gaan die beeldskap op in medemenslikheid, omdat die beeldskap na vore sou kom in die man-vrouverhouding. Ander teoloë vergelyk die 
verhouding tussen man en vrou met die drie-eenheid van God. Soos wat die Goddelike wese se eenheid uit verskillende persone bestaan, is die man en vrou verskillende manifestasies van dieselfde wese (vgl. Van Wyk, 1993:16). Dat die beeldskap nie eksklusief in die verhouding tussen man en vrou opgaan nie, blyk uit die feit dat die mens in Genesis 1:27 kollektief beeld van God genoem word, terwyl die beeldskap elders eksklusief op die man betrek word (Gen. 5:3; vgl. Wentsel, 1987:594). Hoewel die beeldskap nie uitsluitlik geld vir die man-vrouverhouding nie, kom die beeld van God tot openbaring in menslike gemeenskap. Menswees is feitlik identies aan medemens-wees (Van Wyk 1987:33). Die liefde tot God kan nooit aanwesig wees sonder dat dit manifesteer in verhoudings met ander nie (Berkouwer, 1957:195; Barth, 1960:228). Die mens is geskape om gemeenskap met mekaar te hê. Hierdie gemeenskap kom veral na vore in die huwelik wat die basisverhouding van medemens-wees vorm.

Omdat God alle mense na sy beeld skep, is alle mense gelykwaardig voor God. God ken as Skepper 'n besonderse waardigheid aan elke mens toe, en eis daarom van die mens om sy medemens se waardigheid te respekteer, deur hom as 'n gelyke te behandel (vgl. Matt. 5:4348). Deur die medemens as 'n gelykwaardige persoon te behandel, word respek vir die Skepper van die mens getoon. Gelykheid het in die Skrif 'n relasionele inhoud en vind sy eksterne maatstaf in God self (vgl. Du Toit, 1988:77). Dit is nie geleë in enige inherente eienskappe van die mens, of in 'n persoonlike outonomie, soos in die Verligting se konsep van gelykheid nie. Die Skrif fundeer eerder die gelykheid van alle mense in die feit dat elke mens voor God te staan kom (vgl. Du Toit, 1988:77).

Die gelykheid van alle mense kom na vore in die feit dat die hele menslike geslag sy eenheid in God vind (Bavinck, 1928:484). Die menslike geslag word in die Skrif as 'n familie voorgehou, wat in 'n verwantskap met mekaar staan (Hand. 17:26). Hierdie verwantskap kom na vore in die feit dat elke mens die lewe as gawe van God ontvang (Gen. 2:7), en dat die Gees van God in elke mens teenwoordig is (Gen. 6:3). God behandel alle mense op 'n gelyke wyse. Die hele mensheid staan onder die seëninge en vervloekinge van die Adamitiese verbond. Elke mens is verantwoording aan God verskuldig. God regeer in sy voorsienigheid oor die lewe van elke mens. Hy laat die son opkom oor goeie en slegte mense en Hy laat reën oor goeie en slegte mense (vgl. Matt. 5:45). Hy gee ook aan alle mense die gemeenskaplike kultuurmandaat om vrugbaar te wees, die aarde te bewoon en te bewerk, en om oor die diere van die aarde te heers (Gen. 1:28). Hierdie opdrag kom sonder onderskeid van geslag, ras of aanleg. 
Geslagsdiskriminasie is daarom onversoenbaar met die oorspronklike beeldskap van die mens. Die gelykheid tussen die verskillende geslagte is geleë in die feit dat sowel die man as die vrou volwaardig as beeld van God geskape word, en dat elkeen afsonderlik as beeld van God voorgehou word (Gen. 1:27 en 5:2). Man en vrou is gelyksoortige wesens. So word die vrou uit die liggaam van die man geskape (vgl. Gen. 2:20-24). Verder word die kultuuropdrag aan sowel man as vrou gegee (Gen. $1: 28)$. Hierdie opdrag word na die sondeval nog steeds gehandhaaf (Gen. 5:1-2).

Die gelykheid tussen man en vrou blyk ook uit die eenwording tussen man en vrou wat in Genesis 2:20-24 beskryf word. In vers 20 word vertel hoe God die vrou as 'n hulp, helper of gelyke van die man skep. Met "hulp, helper of gelyke" word nie bedoel dat die vrou 'n minderwaardige wese teenoor die man is nie, maar wel dat die vrou 'n soortgelyke wese as die man is, waarmee hy medemenslike gemeenskap kan hê. Dit gaan hier aan die een kant oor 'n "equivalente, volwaardige tegen overlike positie" (Wentsel, 1987:630). Aan die ander kant druk die begrip ook 'n funksionele differensiasie tussen man en vrou uit in die sin dat die vrou die man aanvul en komplementeer. Die gelyke verhouding tussen man en vrou blyk verder uit verse 23-25. Jesus beroep Hom in Matteus 19:4-6 op Genesis 2:23-25, wanneer Hy die patriargale gebruik van mans wat om ligvaardige redes van hulle vrouens skei, as strydig met die oorspronklike bedoeling van God met die huwelik beskryf. Hy beroep Hom spesifiek op die feit dat die huwelik 'n eenwording tussen man en vrou is. Wat God saamgevoeg het, mag die mens nie skei nie (Matt. 19:6). Hiermee word in beginsel gestel dat man en vrou religieus-eties en sosiaal-kultureel 'n hoë en duur waarde besit. Nêrens in die skeppingsverhaal is daar sprake van 'n hoër-laer of meerderwaardige-minderwaardige verhouding tussen man en vrou nie (vgl. Wentsel, 1987:629).

Die sondeval bring onreg en ongelykheid in die wêreld. Dit tas die mens se beeldskap van God aan, maar vernietig dit nie (vgl. Gen. 9:6; Ps. 8; Jak. 3:9). God se antwoord op die sondeval is dat Hy sy skepping dadelik weer begin herskep (vgl. Gen. 3:15). Die herskeppende werk van God bestaan daarin dat God sy aanvanklike orde van reg op aarde kom herstel. In die herstel van God se orde gaan dit oor 'n herstel van God se geldende Wil, en 'n herstel van die mens as beeld van God om sy Godgegewe struktuurmoontlikhede weer te kan verwerklik. Hierdie herskeppende werk van God kom ter sprake in die begrip geregtigheid.

\subsubsection{Geregtigheid in die Ou Testament}

Die stam צַּרּיק word gewoonlik in Afrikaans met "geregtigheid" vertaal.

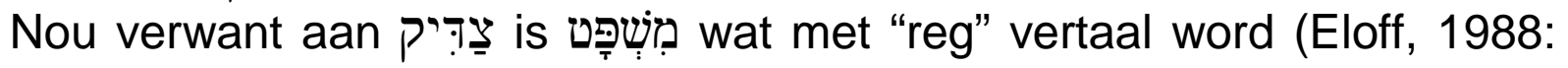




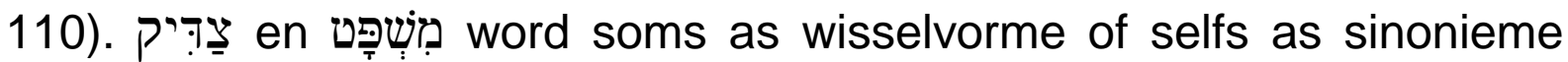
gebruik (vgl. Du Plessis, 1978 en Eloff, 1988:121). Oor die algemeen is

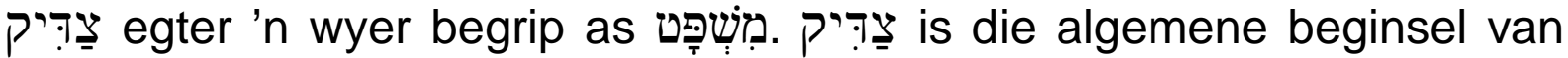
geregtigheid, terwyl מִֹשְָָּּט die konkrete norm is wat binne 'n juridiese en institusionele verband gekonkretiseer word (vgl. Eloff, 1988:121 en Weinfeld, 1992:236). צַדּריק dui in die eerste plek op 'n norm waaraan binne 'n spesifieke situasie gekonformeer moet word (Gosai, 1993:48).

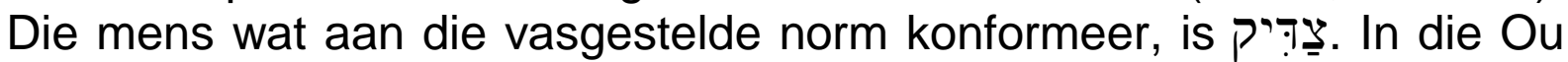
Testament word God aangedui as die norm, bron en maatstaf van alle menslike geregtigheid (Eloff, 1988:113). God self is die Lewende Gewer en die beliggaming van geregtigheid. Sonder God se aktiwiteit kan die mens nie in 'n regte verhouding tot Hom staan nie, maar sonder sy wilsopenbaring van wat geregtigheid is, kan die mens ook nie in 'n regverdige verhouding tot sy medemens staan nie (Eloff, 1988:113). Om צִ צִדּיק te wees beteken dat die mens moet konformeer aan die norm wat deur God gestel word, in sowel sy uiterlike optrede as sy innerlike gesindheid (Gosai, 1993:51).

Geregtigheid is allereers 'n aktiwiteit wat God as Geregtige self uitoefen. God se geregtigheid vloei voort uit sy heiligheid. Omdat God volmaak en heilig is, kan Hy nie anders as om in ooreenstemming met sy wese op te tree nie. Sy gebooie getuig daarom altyd van geregtigheid (vgl. Bouwman, 1899:48 en Ps. 119:7). God se dade van geregtigheid word gekenmerk deur 'n verskeidenheid eienskappe soos sy reddende genade, betroubaarheid, regverdige handelinge, dade van regverdigmaking, regverdige regspraak en wetgewing (vgl. Neh. 9:8; Deut. 32:4; Ps. 129:4; Deut 4:6).

Geregtigheid is nie alleen 'n Goddelike aktiwiteit nie, maar dit is ook 'n Goddelike opdrag aan die mens. As bron en norm van geregtigheid is God ook die normeerder van geregtigheid. Op grond van sy eie geregtigheidsdade eis God van die mens geregtigheidsdade. Die mens moet voldoen aan die norm wat God stel. Dan sal hy צִ wees.

God se geregtigheidseise word aan die mens gegee binne die raamwerk van die verbond. Die genadeverbond tussen God en sy volk is die weg waarlangs geregtigheid verwerklik word (vgl. Gen. 18:19; Deut. 6:25). Die verbondsraamwerk waarbinne צַּרּיק voorkom, stempel geregtigheid as 'n verhoudingsterm wat na 'n verhouding tussen twee partye of persone verwys, en 'n optrede veronderstel wat ooreenkom met, of trou is aan die eise wat uit so 'n verhouding ontstaan ( $\mathrm{vgl}$. Lion-Cachet, 1994:249 en Von Rad, 1969:383). God se geregtigheids- en verbondseise aan die volk word in die wet, en spesifiek in die Tien Gebooie, gevind. In die wet word die grondslag gelê vir 'n regverdige samelewing, 
waarin God sy regmatige eer ontvang en die belange van mense veilig gestel word (vgl. Wentsel, 1973:50).

Die menslike geregtigheid wat die Ou-Testamentiese wette vereis, omvat verskillende soorte geregtigheid soos kultiese geregtigheid en sosiaaletiese geregtigheid. Ten opsigte van gelykheid is die eis tot sosiale geregtigheid van belang. Sosiale en institusionele geregtigheid kom in

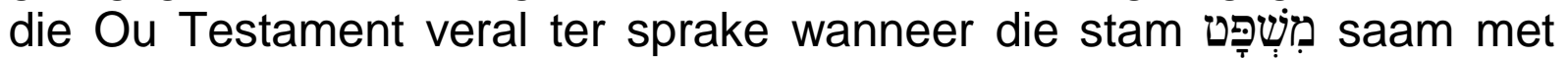

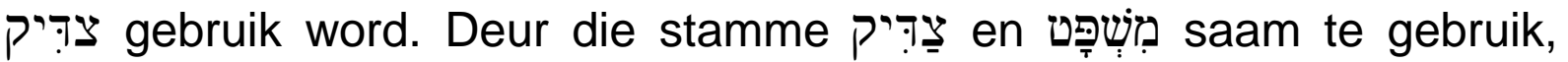
word ' $n$ institusionele en barmhartigheidsdimensie aan geregtigheid verleen (vgl. Weinfeld, 1992:228). Dit gaan in hierdie begrippe oor 'n "social justice and equity, which is bound up with kindness and mercy" (Weinfeld, 1992:238). Die verbondsvolk as geheel word opgeroep om as individue in terme van die verbond reg op te tree en reg te laat geskied (vgl. Eloff, 1988:119; Eks. 23:6; Ps. 94:15; Spr. 12:5; Spr. $21: 3$ en Amos $5: 1)$.

'n Belangrike element van die sosiale geregtigheid in die Ou Testament is die erkenning van die fundamentele gelykheid van alle Israeliete.

Die antieke Israelitiese samelewing was, veral in die stamperiode, 'n egalitêre samelewing met 'n egalitaristiese etos. Israel het homself as een broederlike gemeenskap gesien wat wesentlik gelyk is. Al die Israeliete het feitlik dieselfde lewenstandaard gehandhaaf, omdat die Israeliete hulle bestaan uit landbou gemaak het en landbougrond op 'n gelyke wyse onder families verdeel is (vgl. De Vaux, 1961:73). Gedurende die monargale periode het daar egter 'n sosiale rewolusie in die Israelitiese samelewing plaasgevind. Israel het weens sosiale, ekonomiese en demografiese faktore toenemend begin om mense te stratifiseer. 'n Ryk heersersklas het ontstaan wat die armes onderdruk het. Amptenare het hulle posisies misbruik om armes uit te buit vir hulle eie gewin (vgl. Amos 3:15, 5:11; Jes. 3:16-24, 5:11-12 en Chirichigno, 1993:139).

Religieuse wetgewing het in reaksie hierop gepoog om die toenemende ongelykhede in die Israelitiese samelewing reg te stel (Chirichigno, 1993:139). Veral die Deuteronomistiese skrywers het die ongelyke aard van die latere Israelitiese samelewing aangespreek deur te wys op die oorspronklike gelykheid van alle Israeliete (Braulik, 1998:223). Die Deuteronomistiese oproep tot gelykheid kom eksplisiet in die wetgewing van Deuteronomium voor. 'n Egalitêre etos word egter ook in die ander wettebundels van die Pentateug gevind.

Die teologiese fundering vir die oproep tot gelykheid word gesoek in God se verlossing van Israel uit die slawerny van Egipte (vgl. Braulik, 
1998:215). Die gelykheid van alle Israeliete is geleë in die vryheid wat God vir die hele volk bewerk het. Die oproep tot erkenning van mekaar se gelykheid word aan die volk voorgehou as 'n Goddelike eis op grond van die feit dat God vir elke Israeliet vryheid uit gebondenheid geskep het. Ongelykheid skep weer onvryheid, en daarom moet ongelykheid beveg word.

Die ideaal van gelykheid word in die Pentateug veral bevorder op sosiale, juridiese en ekonomiese terreine.

\section{Sosiale gelykheid}

Wanneer gekyk word na die burgerlike wetgewing van die Pentateug, is dit opvallend dat geen hoër-laer klasse-onderskeidings tussen verskillende sosiale groepe gemaak word nie. Inteendeel, klasseonderskeidings moet ten alle koste vermy word. In die boek Deuteronomium word die konsep van broederskap gebruik om die prinsipiële gelykheid tussen alle Israeliete aan te toon. Israel is deur God bevry om as broeders saam te leef. Die woord הזא, wat met broeder vertaal word, sluit alle geslagte in (Braulik, 1998:223).

Om broederlike solidariteit binne die Israelitiese gemeenskap te verseker word grense gestel aan die mag van persone wat openbare ampte beklee. Die koning word byvoorbeeld in Deuteronomium 17:18-20 beveel om homself ondergeskik te stel aan die wette van Jahwe. Gehoorsaamheid aan die wette van Jahwe sal verseker dat die koning hom "nie bo sy volksgenote verhef en 'n haarbreedte afwyk van hierdie gebod nie" (vers 20).

Die minderbevoorregte deel van die samelewing, soos die armes, weduwees, weeskinders, vreemdelinge en slawe moet ook soos broers behandel word (vgl. Deut. 15:2, 12 en 23:20). Die Israeliet het 'n broederlike plig om vrygewig te wees teenoor sy arm broer (Deut. 15:10, 22:25). Vreemdelinge mag nie "onderdruk" word nie, maar moes soos medeburgers behandel word (Lev. 20:34). Hulle regte mag ook nie van hulle af weggeneem word nie (Deut. 24:17). Die vreemdelinge moes ten volle geïntegreer word in die Israelitiese samelewing (Deut. 23:16). Die regte van die weduwee en weeskind moes ook gerespekteer word (Deut. 24:17 en Eks. 22:22). Die broederlike behandeling van die vreemdeling, weeskind en weduwee word gefundeer in die feit dat God ook hulle God is, en dat die Israeliete self vreemdelinge in Egipte was (Lev. 19:34 en Deut. 10:19). Selfs die slawe moes op 'n broederlike wyse behandel word. Die slawe is beskou as deel van die huisgesin (De Vaux, 1961:85). Hulle het al die regte en pligte gehad wat die res van die verbondsvolk gehad het (Chirichigno, 1993:177). Die slawe het deel gehad aan die aanbidding in die familie (Eks. 23:12), die viering van feeste (Deut. 16:11 
en 14; Eks. 12:44), en kon selfs deel in die meester se erflating (Pred. 17:2; De Vaux, 1961:85).

In Deuteronomium kulmineer die opheffing van klasseverskille in die feeste wat gevier is. Omdat Israel een familie was, moes hulle die feeste ook as een familie vier (Braulik, 1998:222). Al die Israeliete, ook die minderbevoorregtes, moes deel hê aan die viering van die fees tot eer van God. Met die viering van die fees van weke en die huttefees word spesifiek genoem dat die slawe, slavinne, Leviete, vreemdelinge, weeskinders en weduwees van die omgewing deel moes hê aan die viering van die fees (vgl. Deut. 16:11 en 15). Met die viering van die sabbat word die fundamentele gelykheid tussen alle Israeliete verder beklemtoon: "die sewende dag is die sabbat van die Here jou God. Dan mag jy geen werk doen nie, nie jy of jou seun of jou dogter of die man of vrou wat vir jou werk, of jou bees of jou donkie of enige dier van jou nie, sodat jou werksmense kan rus net soos jy" (Deut. 5:14). Die uitdrukking "soos jy" dui daarop dat dit hier gaan oor die reg van minderbevoorregtes om ook hulle gelykheid te kan ervaar voor God. Deurdat die vrye Israeliete die onvrye lede van hulle huishouding toelaat om soos hulleself die sabbat te vier, aanvaar hulle nie net die onvrye lede as hulle gelykes nie, maar hulle tree ook op 'n wyse op wat herinner aan die bevrydingswerk van God (Braulik, 1998:215).

\section{Gelykheid voor die reg}

Gelykheid voor die reg, word soos sosiale gelykheid, voorgehou as 'n fundamentele voorwaarde vir geregtigheid in die Israelitiese samelewing. Elke Israeliet het daarom die reg om homself op 'n regter te kan beroep (Lion-Cachet, 1994:254). Onregverdige regspraak bedreig die fundamentele gelykheid van alle Israeliete. Die regspraak moet regverdig wees, want God is 'n regverdige God wat onreg straf en verontregtes bystaan (Eks. 22:22, 23:6). Die minderbevoorregtes se gelykheid voor die reg is spesifiek beskerm, omdat hulle veral kwesbaar was vir partydigheid voor die reg.

\section{Ekonomiese gelykheid}

Die soeke na ekonomiese gelykheid in Bybelse wetgewing is 'n duidelike bewys van die egalitêre etos wat binne Israel voorgekom het. In die Pentateug word verskeie maatreëls ingevoer om die groeiende ekonomiese ongelykheid tussen die Israeliete teen te werk. Die sabbatsjaar en jubeljaar is ingestel om ' $n$ einde te bring aan die proses waardeur families hulle eiendom verloor het, in skuld verval het, en gevolglik verslaaf is (vgl. De Vaux, 1961:73). Elke sewende jaar was 'n sabbatsjaar gewees. In hierdie jaar moes al die Israelitiese slawe vrygelaat word, behalwe as hulle verkies het om slawe te bly (Deut. 15:12; Eks. 21:2). 
Alle skuld van mede-lsraeliete moes voorts afgeskryf word en die lande moes braak laat lê word, sodat die armes iets kon hê om te eet (Deut. 15:1-3; Lev. 25:6-7). Die jubeljaar moes ooreenkomstig Levitikus 25 elke vyftigste jaar plaasvind. Gedurende hierdie jaar moes die lande braak laat lê word (25:11), eienaars kon hulle oorspronklike grond terugkry $(25: 13,25-28)$, daar was 'n landwye afskrywe van skuld (25:10), en slawe is vrygelaat, sodat hulle weer vrymense kon word wat hulle familiegrond kon bewoon $(25: 41,47,48)$. Die teologiese begronding wat vir die bogenoemde voorskrifte gegee word, is tweërlei: Eerstens behoort die land aan God, met die gevolg dat geen Israeliet die land permanent kan besit nie (25:23). Tweedens kan geen Israeliet permanent 'n slaaf word nie, omdat God Israel uit die slawerny van Egipte bevry het (25:46). Deur die instelling van die sabbatsjaar en jubeljaar is gepoog om die sosiale wanbalanse in die Israelitiese gemeenskap reg te stel. Die hele gemeenskap van Israeliete moes as broeders deel kry aan die Goddelike seëninge wat God aan die volk skenk, nadat Hy hulle uit Egipte uitgelei het.

Behalwe vir die sabbatsjaar en hersteljaar was daar verskeie ander maatreëls wat ekonomiese gelykheid verseker het, soos die spesiale tiendes wat elke drie jaar aan die minderbevoorregtes gegee is (Deut. 14:29), die onafgeoeste deel van die lande wat vir minderbevoorregtes agtergelaat is (Deut. 24:19; Lev. 19:9, 10, 23:22), en die verbod op wins uit rente (Deut. 23:19 en Lev. 25:37).

Uit bogenoemde gegewens blyk dit duidelik dat die fundamentele gelykheid tussen alle Israeliete as ideaal gestel is. Gelykheid hang ten nouste saam met die vryheid om Godgegewe struktuurmoontlikhede te kan verwerklik.

\subsection{Gelykheid in die Nuwe Testament}

Die Nuwe Testament spel, weens die sekulêre staatkundige milieu waarin die gelowiges hulleself bevind het, nie die sosiale en staatkundige implikasies van gelykheid so duidelik uit as die Ou Testament nie. Tog is daar 'n wesentlike kontinuïteit tussen die Ou en Nuwe Testament wat die teologiese fundering van gelykheid betref. Soos in die Ou Testament, bestaan die gelykheid van die menslike geslag daarin dat alle mense na die beeld van God geskape is, en voor God bestaan (vgl. Jak. 3:9). Alle mense word deur God geroep, het verantwoordelikhede voor God, en kom voor sy oordeel en gerig te staan (vgl. Matt. 5:45). Gelykheid hang ook ten nouste saam met geregtigheid. 


\subsubsection{Nuwe-Testamentiese geregtigheid}

Geregtigheid word in die Nuwe Testament hoofsaaklik uitgedruk met die Síkatos-woordgroep. Die mees sentrale begrippe in hierdie woordgroep

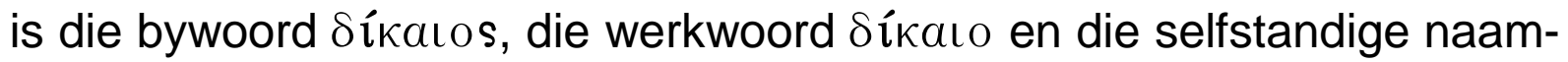

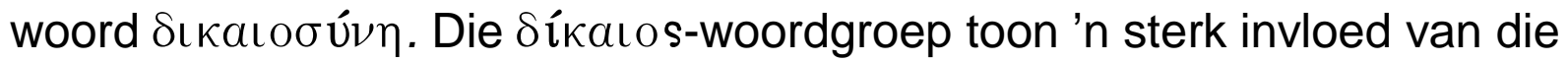
Ou-Testamentiese geregtigheidsbegrip, maar bevat ook nuwe elemente wat verband hou met die nuwe bedeling wat Christus tot stand bring (vgl. Quell \& Schrenk, 1964:188).

Soos in die Ou Testament setel die Nuwe Testament se verstaan van geregtigheid in God se wil vir die skepping. Wanneer van God se geregtigheid gepraat word, word enersyds gepraat van sy oordelende regterlike aktiwiteit en andersyds van sy verlossende en vrysprekende aktiwiteit in Christus (vgl. Quell \& Schrenk, 1964:188, en Eloff, 1988: 132). Hieruit kan reeds afgelei word dat geregtigheid in die Nuwe Testament wesentlik 'n eskatologiese en forensiese inhoud het. Die inhoud is eskatologies omdat geregtigheid te doen het met God se komende gerig, en forensies omdat geregtigheid gaan oor die vryspraak wat die mens in Christus kan kry.

Die eskatologiese geregtigheid van God kom gevolglik reeds in die hede in Christus tot openbaring (vgl. Ridderbos, 1966:181). Christus is die Regverdige waarvan geprofeteer is (Hand. 3:13; 7:52), waardeur die geregtigheid van God 'n gerealiseerde werklikheid word. Hy het die wil van die Vader volkome volbring deur volmaak gehoorsaam te wees aan die wet van God. Op hierdie manier word Hy vir die mens die volmaakte eskatologiese beliggaming van wat geregtigheid is. Die geregtigheid van God in Christus is nie net regterlik en veroordelend van aard nie, maar ook forensies, vrysprekend en verlossend van aard. Christus se opstanding uit die dood is 'n toonbeeld van die nuwe bedeling van God wat deurbreek na die aarde. Die nuwe bedeling is ' $n$ bedeling van vryspraak en genade waarin die mens op grond van die plaasvervangende offer van Christus en sy volmaakte gehoorsaamheid aan die wet regverdig verklaar word voor God (vgl. Rom. 3:25; 5:9, 10). Die geregtigheid van die mens is dus 'n toegerekende geregtigheid (iustitia aliena - vreemde geregtigheid), 'n heilsgawe van God aan die mens.

Deur die regverdigmaking van Christus ontvang die mens 'n nuwe status voor God. Die mens se staat van skuld teenoor God verander na 'n staat van vrede met God (Rom. 5:1). Die mens se kindskap van God, en sy oorspronklike status met die skepping, word so as' t ware weer aan hom toegeken (vgl. Van Genderen \& Velema, 1992:557). Hierdie toege- 
rekende geregtigheid kan die mens alleen deelagtig word langs die weg van die geloof, wat bestaan uit 'n aanvaarding en toe-eiening van die werk van Christus (vgl. Rom. 3:22, 25, 30; Gal. 2:16; Ef. 2:8 en Fil. 3:9).

Die nuwe status wat God aan die mens skenk, het 'n etiese dimensie. God skenk geregtigheid, maar Hy eis dit ook. Volgens Quell en Schrenk

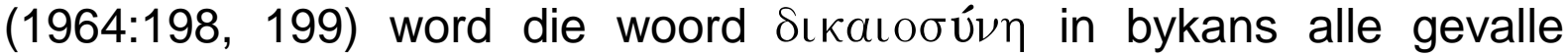
gebruik in verband met 'n regte optrede ooreenkomstig die wil van God. Die mens se nuwe status van geregtigheid voor God lei tot 'n nuwe lewe wat gekenmerk word deur geregtigheidsoptrede. Veral in die brief Jakobus word die feit beklemtoon dat die geloof, wat deur geregtigheid bewerkstellig word, tot 'n goeie lewe lei (vgl. Du Plessis, 1978:221 en Jak. 2:14-16 en 3:18).

Hierdie soeke na geregtigheid vind plaas binne die kader van die liefde. Daar kan geen sprake wees van geregtigheid sonder liefde nie. Terselfdertyd kan die liefde nie anders as om instrument van geregtigheid te wees nie (vgl. Du Toit, 1991:446). Soos in die Ou Testament is die liefde in die Nuwe Testament die diepste motivering vir gehoorsaamheid aan die Wet van God. In Matteus 5:20 stel Jesus dat alleen 'n geregtigheid gedryf deur die liefde genoegsaam is om die koninkryk van God binne te gaan. Die rede hiervoor is dat liefde veranker is in die wese van God, want God is liefde (1 Joh. 4:8).

Die liefde is die instrument waardeur die gelykheid tussen die gelowiges gestalte moet kry. In die Bybelse begrip liefde is ' $n$ fundamentele element van gelykheid opgesluit. Volgens Jesus bestaan die liefde daarin dat jy "jou naaste moet behandel soos jy self behandel wil word" (Luk. 6:31). Op 'n ander plek beskryf Hy naasteliefde as: "Jy moet jou naaste liefhê soos jouself" (Mark. 12:31). Die liefde word beskryf as 'n gelyke behandeling op grond van 'n gelyke waardigheid voor God.

Sowel geregtigheid as liefde veronderstel 'n gelyke behandeling van mekaar voor God. God se geregtigheid vereis dat alle mense hulle naaste so moet behandel dat die "naaste" aan God se reg kan voldoen. Dit kan alleen gebeur as die "naaste" se fundamentele gelykwaardigheid en gelyke verantwoordbaarheid voor God erken word. Die liefde as instrument van God se geregtigheid vereis terselfdertyd dat die naaste behandel moet word "soos ek self graag behandel wil word" (vgl. Mark. $12: 30$ en 31). Omdat alle mense gelykwaardig is voor God, moet mense mekaar as gelykwaardiges behandel. 


\subsubsection{Die mens as beeld van God en die eis tot navolging van Christus}

Aangesien Christus die verpersoonliking van God se geregtigheid en liefde is, moet die gelowige gelykvormig word aan die beeld van Christus. Die Nuwe Testament toon Christus aan as die volmaakte beeld van God. In 2 Korintiërs 4:4 en 6 word Christus die $\epsilon \hat{i} \kappa \omega ́ \nu$ tôे $\theta \in \mathrm{ov}$ genoem wat die kennis ( uitstraal. Die woord $\epsilon \dot{i} \kappa \omega \dot{v}$ tôे $\theta \in o \hat{v}$ is 'n sinspeling op die oorspronklike beeldskap van die eerste mens (vgl. Wentsel, 1987:591). Christus se volmaakte beeldskap word deur Paulus in verband gebring met die heerlikheid ( $\delta$ ó $\xi \alpha$ ) van God. Uit Christus straal die heerlikheid van God self ( 2 Kor. 4:6). As beeld van God is Christus 'n suiwere weerkaatsing

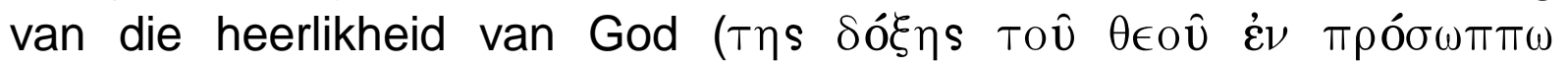
X van Christus aangevoel kan word (2 Kor. 4:6 en Van Genderen \& Velema, 1992:105). Wie vir Christus sien, sien daarom vir God (vgl. Joh. 1:14). In Kolossense 1:15 word Christus weereens $\epsilon \hat{i} \kappa \omega \hat{v} v$ тôे $\theta \in \mathrm{O} \hat{v}$ genoem. Hy is beeld van die onsigbare God ( Tôे). Wat vir die mens onsienlik was, word nou in Christus sigbaar.

Aangesien Christus die volle wese van God beliggaam en die heerlikheid van God uitstraal (Kol. 2:9), word die mens opgeroep om gelykvormig ( $\sigma$ ú $\mu$ орభоus) te word aan die beeld van Christus (vgl. Rom. 8:29). In 2 Korintiërs 3:18 word die vernuwing van die uitverkore mens se beeldskap toegeskryf aan die werking van die Heilige Gees. Die hernuwing van die beeldskap word aangetoon as 'n eskatologiese gawe van God aan die mens - 'n gawe wat nou reeds bestaan, en met die tyd stelselmatig deur die Heilige Gees voltrek word. In Efesesiërs 4:24 en Kolossense 3:10 word die inhoud van die beeldskap wat gelykvormig aan die beeld van Christus is, aangetoon as kennis, geregtigheid en heiligheid.

Die gelykvormigwording aan die beeld van Christus veronderstel 'n lewe wat gekenmerk word deur 'n navolging van Christus. Die Griekse woorde wat in die Nuwe Testament vir die navolging van Christus gebruik word,

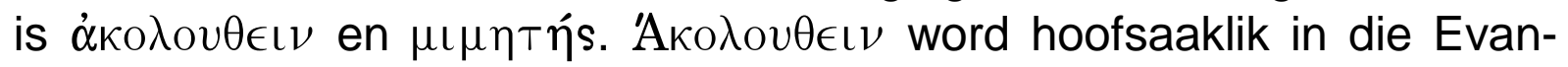
gelies gebruik, terwyl $\mu \iota \mu \eta \tau \eta$ in die briewe van Paulus gevind word. In albei begrippe gaan dit nie oor 'n nabootsing van die voorbeeld van Christus nie, maar wel oor 'n erkenning van Jesus as Messias. Ook gaan dit oor die deelgenootskap van die gelowige aan die gawe van verlossing. Die opdrag aan die gelowige wat daaruit voortvloei, impliseer gemeenskap met die lyde van Christus. Hierdie deelhê word teweeggebring deur 'n lewe van onvoorwaardelike gehoorsaamheid aan die 
Woord en wil van God, en selfverloënende opoffering ter wille van die nalatenskap van Christus.

Die vraag is hoe lyk die navolging in die praktyk? In die Nuwe Testament word die navolging van Christus telkens gerig op die naaste. Gehoorsaamheid aan Christus beteken om soos ( $\dot{\omega} s, \kappa a \theta \dot{\omega} s$ ) die voorbeeld van Christus teenoor die naaste op te tree (vgl. Fil. 2:5; Kol. 3;13; Ef. 4:32). Nêrens word Jesus self die mikpunt van die navolging gemaak, in die sin dat die mens dieselfde vir Christus moet doen as wat Hy vir die mens gedoen het nie. Die mens is die mikpunt van die navolging van Christus. Duvenage (1954:77) stel dit soos volg: "Die navolging van Christus omvat dade en konkrete eise, waarvan die mikpunt, doel en gestaltegewende prinsipe die naaste is."

Hieruit kan tot die gevolgtrekking gekom word dat 'n ware navolging van Christus neerkom op 'n lewe waarin hoë waardering vir die gelykwaardigheid van ander getoon word. Hierdie respek vir die gelykwaardigheid van ander geld nie net vir die onmiddellike naaste nie, maar alle mense (vgl. Matt. 5). Respek vir die gelykwaardigheid van die mens setel in die feit dat God die mens in sy liefde waardig behandel, met die gevolg dat mense mekaar ook waardig moet behandel deur liefde aan mekaar te betoon. Aangesien die gelykwaardigheid van die mens in sy Godgegewe moontlikhede en bestaan voor God setel, mag die mens se gelykwaardigheid nie deur ander mense van hom ontneem word nie, want dit kom neer op opstand teen God. Veel eerder kom die opdrag van God na die mens om respek te toon vir die waardigheid van ander, deur sy naaste in staat te stel om volgens sy Godgegewe moontlikhede te kan handel. Dit geskied wanneer mense mekaar in liefde behandel. Die ware liefde is immers altyd gerig op God, en word beoefen teenoor die naaste, sodat God daardeur geloof en geprys sal word.

\subsubsection{Soteriologiese gelykheid, funksionele differensiasie en die liefde}

Die Nuwe Testament erken in die eerste plek die soteriologiese gelykheid van die gelowiges in Christus. Alle gelowiges word sonder verdienste uit genade gered (Rom. 3:23 en 24). Die geregtigheid wat die gelowige ontvang, is nie 'n verworwe geregtigheid nie, maar wel 'n geskenk van God aan die mens. Geen gelowige mag sy verlossing daarom aan enige menslike verdienste toeskryf of op homself roem nie. Die onverdienstelike geregtigheid wat die mens as geskenk van God ontvang, is die fundamentele rede waarom alle gelowiges in Christus gelyk is. Daarom verklaar Paulus, ondanks die hiërargiese sosiale samestelling van sy tyd, dat alle gelowiges gelyk is in Christus: "Dit maak nie saak of iemand Jood of Griek, slaaf of vry, man of vrou is nie: in Christus is julle almal een" (Gal. 3:28). Enige ontkenning van hierdie 
soteriologiese gelykheid sou afbreuk doen aan die reddende genade van God.

Die soteriologiese gelykheid tussen die gelowiges neem nie die ongelykheid van gawes en talente tussen die gelowiges weg nie. God deel sowel geestelike as natuurlike gawes op 'n ongelyke wyse in die kerk uit (vgl. 1 Kor. 12:30). Die verskillende wyses waarop Hy die gawes uitdeel, en die verskillende gawes wat Hy uitdeel, dien egter die funksionaliteit van die liggaam van Christus. Deur die verskeidenheid van gawes word die eenheid gedien. God skenk immers aan die gelowiges gawes sodat dit tot opbou van die liggaam van Christus (die kerk) gebruik kan word (1 Kor. 14:12). Die geestesgawes is daarom nie privaatbesit nie, maar moet aangewend word ter wille van die solidariteit en gemeenskaplikheid waardeur die gelykheid van die hele gemeenskap gedien word. Gelykheid word juis deur funksionele differensiasie bevorder.

Paulus pas hierdie selfde idee van funksionele differensiasie toe op die huwelik (Ef. 5). Die eenheid tussen man en vrou in die huwelik word bewerkstellig deur die liefde. Manlike en vroulike liefde is egter nie totaal gelyksoortig nie. Die liefde van die man bestaan uit 'n beskermende liefde, terwyl die vrou se liefde bestaan uit eerbied vir haar man. Die twee vorme van liefde komplementeer mekaar en bind die huwelik tot 'n eenheid saam. Daarom kan Paulus in vers 21 die opdrag gee: "Wees uit eerbied aan mekaar onderdanig."

Binne die kerk dien die liefde altyd as die samebindende faktor. Dit verseker eenheid in die kerk. Daarom kan die liefde nooit individualisties of hoogmoedig beoefen word, soos die gelowiges van Korinte deur die beoefening van hulle geestesgawes gedoen het nie. Die liefde is medemenslik en solidêr van aard. Dit is juis vanweë sy samebindende krag die uitnemendste van al die gawes wat God aan die kerk skenk (1 Kor. 13).

Uit die bostaande word dit duidelik dat Bybelse gelykheid nie 'n ontiese, statiese en verhoudinglose toestand is wat sy normering in inherente eienskappe van die mens vind nie. Dit is 'n relasionele begrip wat sy normering in God vind, en samebindend, solidêr en gemeenskapstigtend te werk gaan. Dit is 'n etiese kategorie wat voortdurend positief gevul moet word deur die beoefening van geregtigheid en naasteliefde.

\section{Enkele opmerkings wat vir die debat oor die vrou in die kerk van belang is}

- Daar is 'n fundamentele verskil tussen die moderne konsep van gelykheid wat in die klassieke liberalisme ontstaan het en in die nuwe 
Suid-Afrikaanse Grondwet neerslag vind, en die Bybelse konsep van gelykheid. In die liberale konsep van gelykheid word gelykheid individualisties gefundeer in die mens self. Gelykheid word gesien as 'n inherente aangebore reg wat die mens besit op grond van sy redelikheid en inherente waardigheid. Die mens het daarom die onvervreembare reg tot gelyke waardigheid, gelyke regte, selfrealisering en eie identiteitsvorming. Geslagsgelykheid impliseer 'n formele eenvormigheid tussen man en vrou. In die moderne Westerse samelewing is daar ' $n$ weerstand teen normatief bepaalde onderskeidings tussen die rolle van man en vrou, omdat sodanige onderskeidings op stereotipering en diskriminasie sou neerkom.

- In die Bybelse konsep van gelykheid word gelykheid gefundeer in die mens se bestaan voor God en gelyke waardigheid voor God. Gelykheid impliseer die gelyke reg tot die verwerkliking van Godgegewe moontlikhede. Die mens is egter met verskillende struktuurmoontlikhede geskape en deur die Heilige Gees toegerus met verskillende gawes. Daarom maak die Skrif ruimte vir 'n funksionele differensiasie in rolle, soos byvoorbeeld in die kerk met betrekking tot geestesgawes, en in die huwelik waar man en vrou verskillende liefdesrolle vervul. Die liefde bind die verskeidenheid egter altyd weer tot 'n eenheid saam. Gelykheid dien die solidariteit van die geloofsgemeenskap, en het daarom 'n sterk kommunale inkleding.

- In sy briewe bou Paulus duidelik voort op die Ou-Testamentiese konsep van gelykheid deur sy behandeling van temas soos die volgende: die mens as die beeld van God, die geregtigheid, die eis tot navolging van Christus, en naasteliefde. Hy handhaaf ook die fundamentele gelykheid tussen man en vrou soos blyk uit Galasiërs 3:28. Die vraag is: Waarom weerhou hy vroue daarvan om in die erediens te onderrig, terwyl hy andersins die fundamentele gelykheid tussen man en vrou in Christus handhaaf? Verskeie moontlikhede bestaan: Spesifieke historiese omstandighede kon daartoe aanleiding gegee het dat hy dit nodig geag het om vroue se vryheid tot uitdrukking tydelik in te perk. Dit kan egter ook wees dat hy nie die weerhouding van vroue uit die amp as ' $\mathrm{n}$ vorm van diskriminasie gesien het nie, maar bloot as 'n vorm van funksionele differensiasie in rolle, soos wat Hy ook ten opsigte van die geestesgawes differensieer en ten opsigte van die rolle van man en vrou in die huwelik.

- Indien Paulus se uitsprake aan 'n funksionele differensiasie te wyte is, bring dit ons voor 'n hermeneutiese probleem te staan, naamlik: is sy onderskeiding tussen manlike en vroulike rolle ewige beginsels of kan rolle verander soos tye verander? In so 'n debat sal ons egter daarop moet let dat gelykheid in die Skrif nie 'n individualistiese en statiese konsep is nie. Dit is 'n relasionele begrip, 'n etiese kategorie wat 
voortdurend positief gevul moet word deur liefde en geregtigheid. Die positiewe inkleding van die etiese kategorie van gelykheid sal in verskillende tye verskillend gevul word, en sal ook in verskillende tye ander praktyke tot gevolg hê. Dit moet verder in gedagte gehou word dat Paulus nie die individu en sy regte as uitgangspunt neem nie, maar wel die solidariteit van die gemeenskap. Gebruike wat in die tyd van Paulus die solidariteit van die Christelike gemeenskap verseker het, kan vandag juis die solidariteit van die Christelike gemeenskap bedreig.

- Hoe dit ook al sy, ons moet daarteen waak om nie die Pauliniese uitsprake vanuit 'n moderne konsep van gelykheid te benader, en hom dan van vooroordele teenoor die vroulike geslag te beskuldig nie.

- Daar moet aan die ander kant ook daarteen gewaak word om nie enkele uitsprake van Paulus soos die sogenaamde "swyggebod" en verwysings na die man as hoof van die vrou geïsoleerd van Paulus se breë konsep van gelykheid te interpreteer nie. Wanneer die Bybelse konsep van gelykheid deeglik bestudeer word, is dit duidelik dat die verwysing na die man as hoof van die vrou in 'n teks soos 1 Korintiërs 11:3 nie in 'n onderdrukkende of hiërargiese verband verstaan kan word nie, maar dat dit wel dui op 'n spesifieke verhoudingsverband binne die huwelik waarin iets van die geestelike eenheid tussen Christus en sy kerk tot uiting kom. Dit is volkome in ooreenstemming met die relasionele inhoud wat die Skrif aan gelykheid gee.

\section{Bibliografie}

BARTH, K. 1960. Church dogmatics III/II. Edinburgh : Clark.

BAVINCK, H. 1928. Gereformeerde dogmatiek. Deel 2. Kampen : Kok.

BERKOUWER, G.C. 1957. De mens het beeld Gods. Kampen : Kok.

BOUWMAN, H. 1899. Het begrip gerechtigheid in het Oude Testament. Kampen : Kok. (D.Phil.-proefskrif.)

BRAULIK, G. 1998. Deuteronomy and human rights. Skrif en Kerk, 19(2):207-229.

CHIRICHIGNO, G.C. 1993. Debt slavery in Israel and the ancient Near East. Sheffield : JSOT.

DE VAUX, R. 1961. Ancient Israel: its life and institutions. Translated by John McHugh. London : Darton, Longman \& Todd.

DU PLESSIS, L.M. 1978. Die juridiese relevansie van Christelike geregtigheid. Potchefstroom : PU vir CHO. (D.Phil.-proefskrif.)

DURANDT, J.J.F. Skepping, mens en voorsienigheid: wegwysers in die dogmatiek. Pretoria : NG Kerkboekhandel.

DU TOIT, D. 1988. Die mens en sy regte: geloof en praktyk in Suid-Afrika. Kaapstad : Zebra.

DU TOIT, D. 1991. 'n Christelike beskouing van menseregte. In die Skriflig, 25(4):439-456.

DUVENAGE, S.C.W. 1954. Die navolging van Christus. Potchefstroom : Pro Rege. 
ELOFF, T. 1988. Staatsowerheid en geregtigheid met besondere verwysing na rasseklassifikasie: 'n teologies-etiese studie. Potchefstroom : PU vir CHO. (Th.D.-proefskrif.)

FOUCHE, H.L. 1988. Genesis 2 en 3. (In Burger, C.W., Müller, B.A. \& Smit, D.J., reds. Riglyne vir prediking oor die Genesisverhale. Woord teen die lig II/3. Kaapstad : NG Kerk-Uitgewers. p. 45-76.)

GOSAI, H. 1993. Justice, righteousness and the social critique of the eighth-century prophets. Series vii: theology and religion. New York : Peter Land.

KEIL, C.F. \& DELITZSCH, F. s.a. Commentary on the Old Testament in ten volumes. Volume 1: the Pentateuch. Grand Rapids, Mich. : Eerdmans.

KÖNIG, A. 1993. Menslike mense: gelowig nagedink deel 5. Oor die mens en die sonde in die praktyk. Johannesburg : Orion.

LION-CACHET, F.N. 1994. Die begronding van geregtigheid: 'n perspektief op die wettebundels van die Pentateug. In die Skriflig, 28(2):247-259.

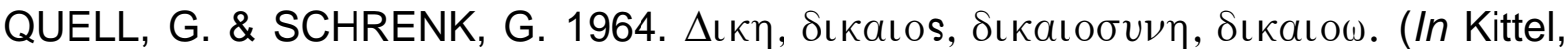
G., ed. Theological dictionary of the New Testament. Volume 2. Translated from the German by Geoffrey W. Bromiley. Grand Rapids, Mich. : Eerdmans. p. 174225.)

RAMSEY, P. 1993. Basic Christian ethics. Louisville : Kentucky.

RIDDERBOS, H. 1966. Paulus: ontwerp van zijn theologie. Kampen : Kok.

SUID-AFRIKA. 1996. Constitution of the Republic of South-Africa as adopted by the Constitional Assembly on 8 May 1996 and as amended on 11 October 1996. (B34B-96.) (ISBN: 0-260-20716-7.)

UNITED NATIONS. 1979. Convention on the elimination of all forms of discrimination against women. Geneva : United Nations.

VAN GENDEREN, J. \& VELEMA, W.H. 1992. Beknopte Gereformeerde dogmatiek. Kampen : Kok.

VAN REENEN, T.B. 1997. Equality, discrimination and affirmative action: an analysis of section 9 of the Constitution of South-Africa. SA Publiekreg, $12(1$ \& 2):79-84.

VAN WYK, J.H. 1987. Etiek en menseregte. In die Skriflig, 21(81):31-40.

VAN WYK, J.H. 1993. Homo Dei: 'n prinsipiële besinning oor enkele mensbeskouings, waaronder dié van Calvyn. In die Skriflig, Supplementum 1.

VAN WYK, J.H. 2000. Persoonlike onderhoud. (Inhoud beskikbaar by outeur).

VENTER, F. 2000. Human dignity as a constitutional value: a South African perspective. Ongepubliseerde artikel.

VON RAD. 1969. Theologie des Alten Testaments. Band 1. Kaiser Verlag : München.

VRIEZEN, T.C. 1966. Hoofdlijnen der theologie van het Oude Testament. Wageningen : Veenman \& Zonen.

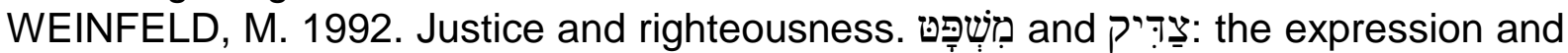
its meaning. (In Reventlow, H.G. \& Hofmann, Y., eds. Justice and righteousness: Biblical themes and their influence. Sheffield : JSOT. p. 228-246.)

WENTSEL, B. 1973. Hij voor ons, wij voor Hem: over gerechtigheid, verzoening en gericht. Kampen : Kok.

WENTSEL, B. 1987. God en mens verzoend: Godsleer, mensleer en zondeleer. Dogmatiek, deel 3a. Kampen : Kok.

\section{Hofsake}

Brink versus Kitschoff no 1996 (6) BCLR 752 (CC)

Harksen versus Lane and others 1997 (11) BCLR 1489 (CC) 
National Coalition for Gay and Lesbian Equality and others versus Minister of Justice and others 1998 (12) BCLR 1517 (CC)

President of the Republic of South Africa and another versus Hugo 1997 (6) BCLR 708 (CC)

Prinsloo versus Van der Linde and another 1997 (6) BCLR 759 (CC)

State versus Makwanyane and another 1995 (6) BCLR 665 (CC)

\section{Kernbegrippe:}

Bybelse gelykwaardigheid gelykheid: posisie van die vrou grondwetlike gelykheid

\section{Key concepts:}

Biblical equality

constitutional equality equality: position of females 